\title{
Interactive Multimedia Module with Pedagogical Agents: Formative Evaluation
}

\author{
Tien Tien Lee ${ }^{1} \&$ Kamisah Osman ${ }^{2}$ \\ ${ }^{1}$ Faculty of Science \& Mathematics, Universiti Pendidikan Sultan Idris, Perak, Malaysia \\ ${ }^{2}$ Faculty of Education, Universiti Kebangsaan Malaysia, Selangor, Malaysia \\ Correspondence: Kamisah Osman, Faculty of Education, Universiti Kebangsaan Malaysia, 43600 Bangi, \\ Selangor, Malaysia. Tel: 60-192-884-814. E-mail: kamisah@ukm.my
}

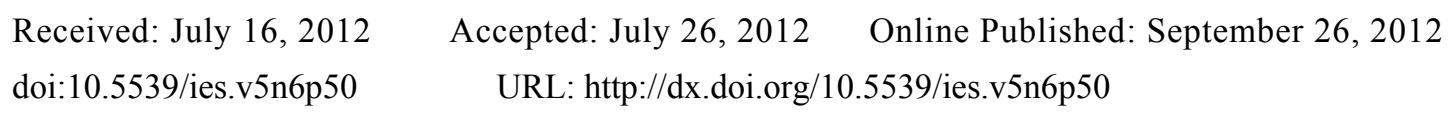

\begin{abstract}
Electrochemistry is found to be a difficult topic to learn due to its abstract concepts that involve three representation levels. Research showed that animation and simulation using Information and Communication Technology can help students to visualize and thus enhance students' understanding in learning abstract chemistry topics. As a result, an interactive multimedia module with a pedagogical agent (IMMPA) named EC Lab was developed to assist students in the learning of Electrochemistry. There were 35 students and seven experts involved in this formative evaluation to test the usability and effectiveness of the module developed. Instruments involved were module evaluation questionnaire, module reliability questionnaire, module validity questionnaire, pretest, post-test and motivation questionnaire. Results showed that the students and experts rated the module developed as high $(\mathrm{M}=3.94)$ and very high quality $(\mathrm{M}=4.45)$. Besides, the respondents also see the module as reliable $(M=3.87)$ and valid $(M=4.51)$. Students have higher scores on their post-test and have gained higher motivation level after learning with the IMMPA EC Lab. However, some corrections and modifications have been made based on feedback and suggestions from the respondents to improve the quality of IMMPA EC Lab.
\end{abstract}

Keywords: interactive multimedia module, pedagogical agent, electrochemistry, formative evaluation

\section{Introducation}

\subsection{Learning of Electrochemistry in Malaysia}

Electrochemistry is the sixth chapter in the Malaysian Chemistry syllabus for secondary schools. This topic is taught to upper secondary level students in the science stream. Electrochemistry is a study of inter-conversion of chemical energy and electrical energy that occurs in electrolytic and voltaic cells. Previous studies (Bojczuk, 1982; Lee \& Kamisah, 2010; Lin, Yang, Chiu \& Chou, 2002; Roziah, 2005) showed that the topic is difficult to learn because the concepts are abstract. Students often encounter misconceptions in the learning of this topic (Garnett \& Hackling 1993; Garnett \& Treagust 1992; Garnett, Garnett \& Hackling, 1995; Karsli \& Çalik, 2012; Lee \& Mohammad Yusof 2009; Lee 2008; Lin et al. 2002; Sanger \& Greenbowe 1997a; Sanger \& Greenbowe 1997b).

Macroscopically, students need to study the concepts of electrolytes and non-electrolytes, the electrolysis process and voltaic cells. Microscopically, they need to understand the movement of ions and electrons during the electrolysis process. Besides that, they need to transform the process into chemical formulae and equations symbolically. Students face difficulties in understanding the abstract chemical processes especially at the microscopic and symbolic levels (Garnett \& Hackling 1993; Garnett \& Treagust 1992; Garnett et al., 1995; Karsli \& Çalik, 2012; Lee \& Mohammad Yusof 2009; Lee 2008; Lin et al. 2002; Sanger \& Greenbowe 1997a; Sanger \& Greenbowe 1997b).

Studies (Doymus, Karacop \& Simsek, 2010; Gois \& Giordan, 2009; Lerman \& Morton, 2009) showed that animation and simulation using information and communication technology (ICT) can help students to visualize and thus enhance students' understanding in learning abstract chemistry topics. The use of multimedia creates the environment where students can visualize the abstract chemical processes via animation and video at macroscopic, microscopic and symbolic levels (Bowen, 1998; Burke, Greenbowe \& Windschitl, 1998; 
Rodrigues, Smith \& Ainley, 2001; Russell, Kozma, Jones, Wykoff, Marx \& Davis, 1997).

Although the use of multimedia modules is able to assist students in visualizing the abstract concepts, students lack sufficient metacognitive awareness and comprehension monitoring skill to make effective choices (Hill \& Hannafin, 2001; Land, 2000) in computer-mediated learning environments. They lack the skills to find, process and use information and ideas. Students as novice learners do not always make connections with prior knowledge or everyday experiences in ways that are productive for learning (Land, 2000). As a result, Pedagogical Agents (PAs) are designed to facilitate learning in computer-mediated learning environments (Chou, Chan \& Lin, 2003; Craig, Gholson \& Driscoll, 2002; Johnson, Rickel, \& Lester, 2000; Moundridou \& Virvou, 2002; Predinger, Saeyor \& Ishizuka, n.d., Slater, 2000).

PAs in the interactive multimedia module serve to enhance students' metacognitive awareness of what they know and what they should know regarding the topic being studied. One of the strategies to provide metacognitive guidance involves embedding support, or scaffolds for procedural, strategic, or metacognitive control (Land, 2000). Such guidance and support are provided by the PAs in the module. PAs could make learners more aware of the opportunities presented to them, provide advice to learners on the tools to be used, and explain the functionalities of the tools in an open learning environment (Clarebout \& Elen, 2007). Hence, an Interactive Multimedia Module with Pedagogical Agents (IMMPA) named EC Lab was developed to assist students in the learning of Electrochemistry.

\subsection{Development of the IMMPA EC Lab}

In this study, we developed IMMPA EC Lab in the learning of Electrochemistry by combining two instructional design models: Kemp Model (1994) and Gerlach and Ely Model (1980). The two models are combined as they are both classroom-oriented (Gustafson \& Branch, 1997) with their own strengths. The model produced through the combination is named KemGerly Model and the conceptual framework of KemGerly Model is illustrated in Figure 1.

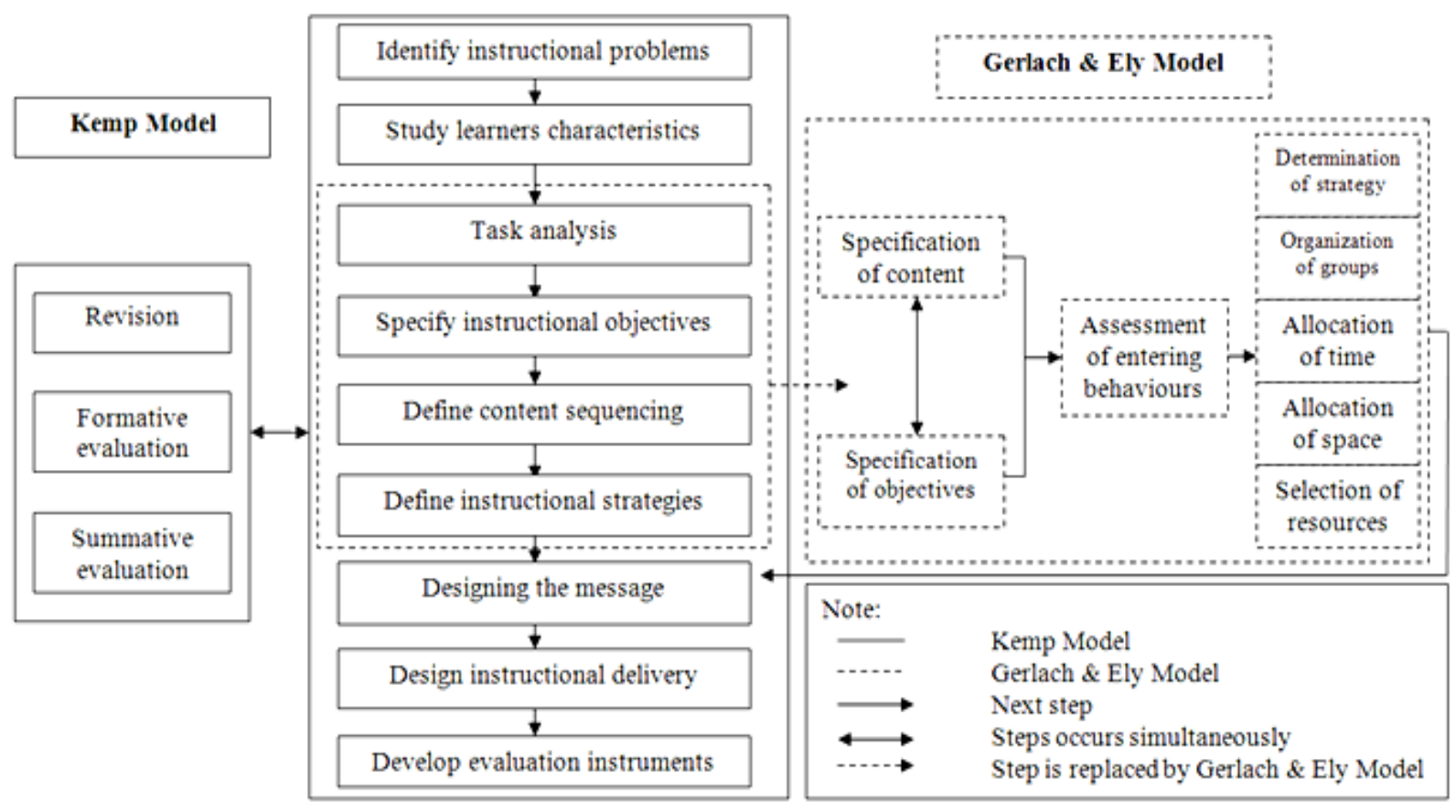

Figure 1. Conceptual framework of KemGerly Model

The Kemp Model describes elements, not steps, stages, levels or sequential items in an instructional design (Kemp, Morrison \& Ross, 2004). The oval shape of the model indicates the independence of the elements in the model. It is a non-linear model with no starting and ending point. All the processes of designing, developing, implementing and evaluating can be done concurrently and continuously. The Gerlach and Ely Model is suitable for novice instructional designers who have knowledge and expertise in a specific context (Qureshi, 2001, 2003, 2004). This model is classroom-oriented and is suitable for teachers at secondary schools and higher education institutions. The Gerlach and 
Ely Model focuses more on instructional materials and resources without identifying instructional problems. Hence, we have combined the two models as the instructional design model to develop the IMMPA EC Lab.

To develop IMMPA EC Lab, first of all, we need to identify instructional problems in Electrochemistry (Lee \& Kamisah, 2010) and study learners' characteristics (Lee \& Kamisah, 2012). Then, the four elements in the Kemp Model were replaced by some steps in Gerlach \& Ely Model. We analyzed the contents of Electrochemistry, specified the learning objectives and assessed students' entering behavior. We also determined the strategy to be used, organized the group, considered the allocation of time and space and finally selected suitable resources in designing the IMMPA EC Lab. Next, we designed the message in the content delivery and arrange the instructional delivery. Evaluation instruments were also developed as the last part of every sub unit in the IMMPA EC Lab to assess students' understanding in each sub unit. When everything was done, a formative evaluation was carried out to evaluate the module developed.

\subsubsection{Formative Evaluation}

The main purpose of the formative evaluation is to inform the instructor or planning team how well the instructional program has been serving the objectives as it progresses (Morrison, Ross \& Kemp, 2007). Hence, the formative evaluation should be conducted at different stages during the development of the IMMPA EC Lab. Dick and Carey (1991) suggested three stages of formative evaluation when designing an instruction, namely one-to-one trials, small-group trials and field trials. Descriptions of the stages with the related instruction phase, purpose, respondents and instruments are displayed in Table 1.

Table 1. Stages of Formative Evaluation

\begin{tabular}{lllll}
\hline Stage & Instruction Phase & Purpose & Learners & Main Measures \\
\hline One-to-one trials & Development & Try-out impressions & Individuals & $\begin{array}{l}\text { Observation, survey, } \\
\text { interview }\end{array}$ \\
$\begin{array}{llll}\text { Small-group } \\
\text { trials }\end{array}$ & $\begin{array}{l}\text { Preliminary/draft } \\
\text { version }\end{array}$ & $\begin{array}{l}\text { Identify } \\
\text { strengths/weakness }\end{array}$ & Small groups (8-20) & $\begin{array}{l}\text { Observation, attitudes, } \\
\text { performance }\end{array}$ \\
& Completed & $\begin{array}{l}\text { Assess actual } \\
\text { implementation }\end{array}$ & Regular classes & Performance, attitudes \\
\hline
\end{tabular}

As shown in Table 1, we carried out one-to-one trials during the development phase. Next, we carried out small-group trials followed by field trials. This paper will concentrate on details of the small-group trials to test whether the module developed is usable and effective in learning Electrochemistry.

Flagg (1990) suggested four types of formative evaluation, namely connoisseur-based studies, decision-oriented studies, objectives-based studies and public relations-inspired studies. In our case, we decided to combine the connoisseur-based study approach and objective-based study approach as our method of formative evaluation. We selected the connoisseur-based study approach because it employs subject matter experts and other appropriate consultants (media and design experts) to examine the instruction and give opinions regarding its accuracy and effectiveness. The IMMPA EC Lab was examined by some experts in Electrochemistry, language experts and instructional designers to maintain the quality of IMMPA EC Lab in terms of content and instructional design. In addition, we administered pre- and post achievement tests and motivation questionnaires to measure the amount of gain on measures of achievement and attitude as the objectives-based study approach.

\subsection{Research Questions and Hypotheses}

The study was carried out as a formative evaluation for the development of IMMPA EC Lab. This formative evaluation is a combination of connoisseur-based study and objectives-based study approaches. The research questions and hypotheses that drive this formative evaluation are as follows:-

1) What is the quality level of IMMPA EC Lab from students' point of view?

2) What is the quality level of IMMPA EC Lab from experts' point of view?

3) Is IMMPA EC Lab a reliable multimedia module in the learning of Electrochemistry?

4) Is IMMPA EC Lab a valid multimedia module in the learning of Electrochemistry?

5) $\mathrm{H}_{01}$ : There is no significant difference between the mean scores in achievement test before and after the intervention.

6) $\mathrm{H}_{02}$ : There is no significant difference between the mean scores in motivation before and after the 
intervention.

\section{Method}

\subsection{Respondents}

Seven experts from different areas (content, chemistry education, instructional design/e-learning) were selected as respondents for the connoisseur-based study. They evaluated IMMPA EC Lab in terms of pedagogical content of Electrochemistry, language, instructional design and validity of the module.

Thirty-five Form Four students were selected as respondents for the objectives-based study to investigate the effect of IMMPA EC Lab on students' knowledge and motivation in learning Electrochemistry. Besides that, they were asked to evaluate the usability of IMMPA EC Lab in terms of quality and reliability of the module. The respondents consisted of 13 male and 22 female students (aged 16 years), and the majority of them are Malays. As for small-group trials, there were 8-20 respondents (Table 1). Hence, it is argued that 35 students in our study are more than enough for the objective-based study.

\subsection{Materials}

Materials utilized in the study are the IMMPA EC Lab, module evaluation questionnaire, module reliability questionnaire, module validity questionnaire, pretest, post-test and motivation questionnaire.

\subsubsection{IMMPA EC Lab}

IMMPA EC Lab was developed using the KemGerly Model. There are two PAs in the IMMPA EC Lab, namely Professor T and Lisa. Professor T is a sixty-year-old male PA who acts as an expert in Electrochemistry. He gives accurate information and explains new concepts to the students. Professor T speaks slowly in a formal way with little body gestures and facial expressions. On the other hand, Lisa is a fifteen-year-old female who speaks with an energetic voice. She is a learning companion in the IMMPA EC Lab. She learns together with the students, as well as motivates and encourages the students to complete the tasks and exercises in the module. Students are free to choose the PA they want to accompany them in learning Electrochemistry when using the IMMPA EC Lab.

The main menu for the IMMPA EC Lab consists of tutorials, experiments, exercises, quizzes, memos and games. There are five sub units in the IMMPA EC Lab: (1) Electrolytes and Non-Electrolytes, (2) Electrolysis of Molten Compounds, (3) Electrolysis of Aqueous Solutions, (4) Voltaic Cells and (5) Types of Voltaic Cells. The complete flow of each sub unit follows the five phases in the learning process created by Needham (1987). The five phases are orientation, elicitation of ideas, restructuring of ideas, application of ideas and review. The relationship between sessions in IMMPA EC Lab and Needham phases is summarized in Table 2 below.

Table 2. Needham Phases and Sessions in IMMPA EC Lab

\begin{tabular}{lll}
\hline Needham Phases & Sessions in every Sub unit & Main Menu \\
\hline Orientation & Think about it! & \\
$\begin{array}{l}\text { Elicitation of Ideas } \\
\text { Restructuring of Ideas }\end{array}$ & Do you still remember? & \\
$\bullet$ Clarification and exchange & Give me your ideas... & Tutorial \\
$\bullet$ Exposure to conflict situation & Are you sure? & \\
$\bullet$ Construction of new ideas and evaluation & Let's do it!! / Show time! & Experiment \\
Application of Ideas & Practice makes perfect! & Exercise \\
Review & Before \& after.. & Quiz \\
& Test yourself & Challenge yourself \\
& & Memo \\
& & Game \\
\hline
\end{tabular}

All the information delivery for the sub units is presented in the tutorial session. The experiment session consists of five experiments. After the information delivery process, the students will attempt some exercises to enhance their understanding on the concepts learnt. A quiz is given at the end of every sub unit. A memo is created to give some notes on Electrochemistry concepts. There are four activities in the game session to let the students relax their mind after the learning process. 


\subsubsection{Module Evaluation Questionnaire}

A module evaluation questionnaire was used to evaluate the quality of the module based on some components in the module. The components and number of items in the module evaluation questionnaire for both student and expert versions are summarized in Table 3. The items for PAs' evaluation components were created according to the agents' characteristics in Agent Persona Instrument (API) by Baylor and Ryu (2003). We referred to previous researches (Baylor, Ryu \& Shen, 2003; Brünken, Plass, \& Leutner, 2004; Chandler \& Sweller, 1992; Craig et al., 2002; Kirk, 2008; Mayer \& Moreno, 1998; Mayer, Dow \& Mayer, 2003; Mayer, Fennell, Farmer \& Campbell, 2004; Mayer, Sobko \& Mautone, 2003; Moreno \& Mayer, 2000; Moreno \& Mayer, 1999; Moreno et al., 2000; Mousavi, Low \& Sweller, 1995; Paas \& Van Merriënboer, 1994; Paas, Renkl \& Sweller, 2003; Pollock, Chandler \& Sweller, 2002; Sweller \& Chandler, 1994; Van Gerven, Paas, Van Merriënboer, \& Schmidt, 2002; Van Merrienboer, Kirschner \& Kester, 2003) to create items about evaluation of Cognitive Load Theory and Cognitive Theory of Multimedia Learning.

Table 3. Components in Module Evaluation Questionnaire

\begin{tabular}{|c|c|c|c|}
\hline \multicolumn{2}{|r|}{ Components } & \multicolumn{2}{|c|}{ Total Items } \\
\hline & & Students & Experts \\
\hline \multirow[t]{7}{*}{ I. } & Screen design & & \\
\hline & A. Text & 4 & 4 \\
\hline & Colour & 4 & 4 \\
\hline & Graphic & 6 & 6 \\
\hline & Animation & 3 & 3 \\
\hline & Video & 3 & 3 \\
\hline & F. Audio & 7 & 7 \\
\hline II. & Navigation \& Interactivity & 13 & 13 \\
\hline III. & Language & 7 & 7 \\
\hline IV. & Content & 11 & 11 \\
\hline $\mathrm{V}$ & Interest \& Motivation & 10 & 10 \\
\hline VI. & Pedagogical agent & & \\
\hline \multirow[t]{5}{*}{ a) } & Professor T & & \\
\hline & A. Facilitating Learning & 10 & 10 \\
\hline & Credible & 5 & 5 \\
\hline & Human-like & 5 & 5 \\
\hline & Engaging & 5 & 5 \\
\hline \multirow[t]{5}{*}{ b) } & Lisa & & \\
\hline & Facilitating Learning & 10 & 10 \\
\hline & Credible & 5 & 5 \\
\hline & Human-like & 5 & 5 \\
\hline & D. Engaging & 5 & 5 \\
\hline VII. & Application of Theory & & \\
\hline a) & Behaviourism Theory & - & 9 \\
\hline b) & Cognitivism Theory & - & 8 \\
\hline c) & Constructivism Theory & - & 12 \\
\hline \multirow[t]{8}{*}{ d) } & Cognitive Load Theory & & \\
\hline & A. Intrinsic cognitive load & - & 8 \\
\hline & Extraneous cognitive load & & \\
\hline & Split attention effect & - & 8 \\
\hline & Worked-example effect & - & 9 \\
\hline & Modality effect & - & 9 \\
\hline & Redundancy effect & - & 5 \\
\hline & C. Germane cognitive load & - & 7 \\
\hline \multirow[t]{8}{*}{ e) } & Cognitive Theory of Multimedia Learning & & \\
\hline & A. Personalization principle & - & 7 \\
\hline & Modality principle & - & 9 \\
\hline & Spatial contiguity principle & - & 7 \\
\hline & Temporal contiguity principle & - & 7 \\
\hline & Redundancy principle & - & 5 \\
\hline & Voice principle & - & 8 \\
\hline & Interactivity principle & - & 11 \\
\hline Total & & 118 & 247 \\
\hline
\end{tabular}


The questionnaire was given to both students and experts to compare the quality of module from their point of view. Similar questionnaires were given to the students and experts with some addition of components in the experts' version.

\subsubsection{Module Reliability Questionnaire}

A module reliability questionnaire was developed by the researchers with reference to the examples suggested by Sidek and Jamaludin (2005). Items in the module reliability questionnaire were developed based on activities in the IMMPA EC Lab because they are better compared to items created based on objectives of the module (Sidek \& Jamaludin, 2005). The distribution of items based on activities in IMMPA EC Lab is summarized in Table 4.

Table 4. Item Distribution in Module Reliability Questionnaire

\begin{tabular}{lc}
\hline Sessions in every Sub unit & Total items \\
\hline Front page of sub units & 3 \\
Objectives & 4 \\
Think about it! & 6 \\
Do you still remember? & 4 \\
Give me your ideas... & 4 \\
Are you sure? & 4 \\
Let's do it!! / Show time! & 7 \\
Practice makes perfect! & 6 \\
Before \& after... & 4 \\
Test yourself! & 4 \\
Challenge yourself! & 4 \\
Total & 50 \\
\hline
\end{tabular}

\subsubsection{Module Validity Questionnaire}

We referred to Sidek's and Jamaludin's suggestions and developed the items in our module validity questionnaire based on characteristics of module validity suggested by Russell (1974). All the characteristics required and the items related are summarized in Table 5.

Table 5. Item Distribution in Module Validity Questionnaire

\begin{tabular}{lc}
\hline \multicolumn{1}{c}{ Characteristics of Module Validity } & Total items \\
\hline Accurate target population & 5 \\
The teaching situation or implementation method is done very well & 5 \\
Enough time to implement the whole module & 5 \\
Potential to increase students' academic achievement & 5 \\
Potential to change students' behavior to be excellent in life & 5 \\
Total & 25 \\
\hline
\end{tabular}

\subsubsection{Achievement Tests}

Achievement tests were administered in the form of pretest and post-test before and after the intervention. There are two structured questions in the achievement tests. The questions test knowledge on electrolytic cell and voltaic cell concepts at the macroscopic, microscopic and symbolic levels. Questions in the pretest and post-test are similar in terms of difficulty level and concept tested. The concepts tested and numbers of items in the achievement tests are summarized in Table 6. 
Table 6. Distribution of Items in Achievement Tests

\begin{tabular}{|c|c|c|c|}
\hline \multirow[t]{2}{*}{ Concept } & \multicolumn{2}{|c|}{ Item Distribution } & \multirow{2}{*}{$\begin{array}{l}\text { Representation } \\
\text { Level }\end{array}$} \\
\hline & $\begin{array}{l}\text { Electrolytic } \\
\quad \text { Cell }\end{array}$ & Voltaic Cell & \\
\hline $\begin{array}{l}\text { Flow of current in the conductors and in the } \\
\text { electrolytes }\end{array}$ & c (i), c (ii) & c (i), c (ii) & Microscopic \\
\hline Identify the anode and cathode & & $\begin{array}{l}\mathrm{k}, 1 \text { (i), } 1 \text { (ii), m (i), m } \\
\text { (ii) }\end{array}$ & $\begin{array}{l}\text { Macroscopic } \\
\text { Microscopic }\end{array}$ \\
\hline $\begin{array}{l}\text { Identify the process happening at the anode and } \\
\text { cathode }\end{array}$ & $\begin{array}{l}\text { a (i), a (ii), } \\
\text { b }\end{array}$ & a (i), a (ii), b & Macroscopic \\
\hline Oxidation and reduction process & $\begin{array}{l}\text { e (i), e (ii), } \\
\text { f }\end{array}$ & e (i), e (ii), f & $\begin{array}{l}\text { Microscopic } \\
\text { Symbolic }\end{array}$ \\
\hline Concept of Electrolyte & $\mathrm{j}$ & $\mathrm{j}$ & Microscopic \\
\hline
\end{tabular}

\subsubsection{Motivation Questionnaire}

The motivation questionnaire is a Likert scale questionnaire. The distribution of items in the motivation questionnaire is shown in Table 7.

Table 7. Item Distribution in Motivation Questionnaire

\begin{tabular}{lc}
\hline \multicolumn{1}{c}{ Sub dimension } & Item Distribution \\
\hline Intrinsic goal orientation & $1,13,19,21$ \\
Extrinsic goal orientation & $6,9,27$ \\
Task value & $8,14,20,23,24$ \\
Control of learning belief & $2,7,15,22$ \\
Self-Efficacy for learning and performance & $4,5,10,12,17,18,26,28$ \\
Test anxiety & $3,11,16,25$ \\
\hline
\end{tabular}

As highlighted in Table 7, there are six constructs involved, namely intrinsic goal orientation, extrinsic goal orientation, task value, control of learning belief construct, self-efficacy for learning and performance and test anxiety. There is a total of 28 items in the questionnaire with the Likert scale ranging from 1 - Strongly Disagree to 5 - Strongly Agree. Items in the questionnaire have been taken from the study of Sadiah and colleagues (2009) which were translated from the instrument used by Pintrich and DeGroot (1990). In this study, the researchers used the motivation section only and changed the scale from seven points to five points.

\subsection{Procedure}

For the connoisseur-based study, the experts were given IMMPA EC Lab, a module evaluation questionnaire and a module validity questionnaire. They need to explore the IMMPA EC Lab and then answer the module evaluation questionnaire and module validity questionnaire.

For the objectives-based study, respondents were given the pretest and motivation questionnaire to gauge their existing knowledge in Electrochemistry and their motivation level before they study Electrochemistry with IMMPA EC Lab. They were given 60 minutes to answer the pretest and 15 minutes to answer the motivation questionnaire. Then the respondents were gathered at the computer laboratory and briefed on how to use the IMMPA EC Lab. Respondents then started to explore the IMMPA EC Lab. Finally, they were given the post-test and motivation questionnaire.

\section{Results}

\subsection{Quality of IMMPA EC Lab}

The quality of the module was determined by the module evaluation questionnaire. Similar questionnaires were given to both students and experts to determine their view on the quality of the IMMPA EC Lab. The students 
rated IMMPA EC Lab as high quality with a mean of $3.94(\mathrm{SD}=0.32)$ while experts rated it as very high quality with a mean of $4.45(\mathrm{SD}=0.40)$. Means for all components in IMMPA EC Lab are shown in Table 8.

Table 8. Mean scores for All Components in Module Evaluation Questionnaire

\begin{tabular}{|c|c|c|c|c|c|c|c|c|}
\hline \multirow{2}{*}{\multicolumn{3}{|c|}{ Components }} & \multicolumn{3}{|c|}{ Students } & \multicolumn{3}{|c|}{ Experts } \\
\hline & & & Mean & SD & Quality & Mean & SD & Quality \\
\hline \multirow[t]{7}{*}{ I. } & \multicolumn{2}{|c|}{ Screen design } & 3.95 & 0.37 & High & 4.37 & 0.35 & Very high \\
\hline & A. & Text & 4.04 & 0.45 & High & 4.71 & 0.30 & Very high \\
\hline & B. & Colour & 4.05 & 0.48 & High & 4.25 & 0.50 & Very high \\
\hline & C. & Graphic & 4.22 & 0.47 & Very high & 4.43 & 0.42 & Very high \\
\hline & D. & Animation & 4.15 & 0.53 & High & 4.62 & 0.41 & Very high \\
\hline & E. & Video & 4.04 & 0.58 & High & 4.10 & 0.42 & High \\
\hline & & Audio & 3.46 & 0.57 & High & 4.18 & 0.56 & High \\
\hline II. & \multicolumn{2}{|c|}{ Navigation \& Interactivity } & 4.10 & 0.40 & High & 4.59 & 0.33 & Very high \\
\hline III. & \multicolumn{2}{|c|}{ Language } & 3.99 & 0.49 & High & 4.65 & 0.32 & Very high \\
\hline IV. & \multicolumn{2}{|c|}{ Content } & 4.21 & 0.40 & Very high & 4.55 & 0.45 & Very high \\
\hline $\mathrm{V}$. & \multicolumn{2}{|c|}{ Interest $\&$ Motivation } & 3.77 & 0.49 & High & 4.20 & 0.59 & High \\
\hline VI. & \multicolumn{8}{|c|}{ Pedagogical agent } \\
\hline \multirow[t]{5}{*}{ a) } & \multicolumn{2}{|c|}{ Professor T } & 3.72 & 0.59 & High & 4.21 & 0.73 & Very high \\
\hline & A. & Facilitating Learning & 3.62 & 0.70 & High & 4.31 & 0.86 & Very high \\
\hline & B. & Credible & 4.06 & 0.61 & High & 4.40 & 0.49 & Very high \\
\hline & C. & Human-like & 3.58 & 0.68 & High & 4.06 & 0.85 & High \\
\hline & D. & Engaging & 3.71 & 0.75 & High & 3.94 & 0.75 & High \\
\hline \multirow[t]{5}{*}{ b) } & Lisa & & 3.84 & 0.38 & High & 4.02 & 0.72 & High \\
\hline & A. & Facilitating Learning & 3.90 & 0.48 & High & 4.01 & 0.66 & High \\
\hline & B. & Credible & 3.75 & 0.50 & High & 4.26 & 0.70 & Very high \\
\hline & C. & Human-like & 3.67 & 0.51 & High & 3.86 & 0.94 & High \\
\hline & D. & Engaging & 3.97 & 0.53 & High & 3.97 & 0.82 & High \\
\hline VII. & \multicolumn{8}{|c|}{ Application of Theory } \\
\hline a) & Beha & viourism Theory & - & - & - & 4.65 & 0.40 & Very high \\
\hline b) & $\operatorname{Cog} n$ & itivism Theory & - & - & - & 4.48 & 0.50 & Very high \\
\hline c) & Cons & tructivism Theory & - & - & - & 4.60 & 0.45 & Very high \\
\hline \multirow[t]{8}{*}{ d) } & \multicolumn{2}{|c|}{ Cognitive Load Theory } & - & - & - & 4.60 & 0.35 & Very high \\
\hline & A. & Intrinsic cognitive load & - & - & - & 4.65 & 0.42 & Very high \\
\hline & & Extraneous cognitive load & - & - & - & 4.61 & 0.35 & Very high \\
\hline & & Split attention effect & - & - & - & 4.54 & 0.47 & Very high \\
\hline & & Worked-example effect & - & - & - & 4.70 & 0.47 & Very high \\
\hline & & Modality effect & - & - & - & 4.83 & 0.21 & Very high \\
\hline & & Redundancy effect & - & - & - & 3.97 & 0.81 & High \\
\hline & & Germane cognitive load & - & - & - & 4.45 & 0.39 & Very high \\
\hline \multirow[t]{8}{*}{ e) } & \multicolumn{2}{|c|}{$\begin{array}{l}\text { Cognitive Theory of Multimedia } \\
\text { Learning }\end{array}$} & - & - & - & 4.57 & 0.31 & Very high \\
\hline & A. & Personalization principle & - & - & - & 4.59 & 0.29 & Very high \\
\hline & B. & Modality principle & - & - & - & 4.79 & 0.20 & Very high \\
\hline & C. & Spatial contiguity principle & - & - & - & 4.65 & 0.35 & Very high \\
\hline & & $\begin{array}{l}\text { Temporal } \\
\text { principle }\end{array}$ & - & - & - & 4.65 & 0.44 & Very high \\
\hline & E. & Redundancy principle & - & - & - & 3.89 & 0.85 & High \\
\hline & F. & Voice principle & - & - & - & 4.39 & 0.59 & Very high \\
\hline & G. & Interactivity principle & - & - & - & 4.73 & 0.23 & Very high \\
\hline Total & & & 3.94 & 0.32 & High & 4.45 & 0.40 & Vey high \\
\hline
\end{tabular}




\subsection{Module Reliability}

A module reliability questionnaire was administered to the students to determine the reliability of IMMPA EC Lab. The students rated the module as highly reliable with a mean of $3.87(\mathrm{SD}=0.41)$. Means for all sessions in the IMMPA EC Lab are shown in Table 9.

Table 9. Mean scores for All Sessions in IMMPA EC Lab

\begin{tabular}{lccc}
\hline \multicolumn{1}{c}{ Sessions in every Sub unit } & Mean & SD & Reliability \\
\hline Front page of sub units & 4.12 & 0.54 & High \\
Objectives & 3.66 & 0.54 & High \\
Think about it! & 3.76 & 0.41 & High \\
Do you still remember? & 3.81 & 0.47 & High \\
Give me your ideas... & 3.96 & 0.60 & High \\
Are you sure? & 3.97 & 0.56 & High \\
Let's do it!!/Show time! & 3.80 & 0.55 & High \\
Practice makes perfect! & 3.91 & 0.49 & High \\
Before \& after... & 4.04 & 0.56 & High \\
Test yourself! & 3.76 & 0.52 & High \\
Challenge yourself! & 3.81 & 0.50 & High \\
\hline
\end{tabular}

\subsection{Module Validity}

A module validity questionnaire was administered to experts to evaluate the module in terms of validity. All the items in the questionnaire were based on the characteristics of module validity. The experts rated IMMPA EC Lab as a very highly valid module $(\mathrm{M}=4.51, \mathrm{SD}=0.20)$. The mean value for each characteristic of module validity is summarized in Table 10 .

Table 10. Mean Scores for each Characteristic of Module Validity

\begin{tabular}{lcccc}
\hline \multicolumn{1}{c}{ Characteristics of Module Validity } & Mean & SD & Validity \\
\hline Accurate target population & 4.66 & 0.32 & Very high \\
The teaching situation or implementation method is done very well & 4.60 & 0.31 & Very high \\
Enough time to implement the whole module & 4.14 & 0.40 & High \\
Potentially to increase students' academic achievement & 4.66 & 0.25 & Very high \\
Potentially to change students' behavior to be excellent in life & 4.51 & 0.45 & Very high \\
Total & 4.51 & 0.20 & Very high \\
\hline
\end{tabular}

\subsection{Achievement Tests}

To carry out the objectives-based studies, achievement tests were given in the form of pretest and post-test before and after the intervention. The results of the pretest and post-test were used to examine the effect of IMMPA EC Lab on students' understanding in Electrochemistry. Table 11 shows the t-test results for the pretest and post-test.

Table 11. T-test table for Students' Achievement Tests

\begin{tabular}{cccccc}
\hline Test & N & Mean & Std. Deviation & t value & Sig (2-tailed) \\
\hline Post-test & 35 & 26.98 & 13.61 & 8.97 & $0.000^{*}$ \\
Pretest & 35 & 9.42 & 5.71 & & \\
\hline
\end{tabular}


A paired-sample t-test was conducted to evaluate the impact of the IMMPA EC Lab on the students' scores in the achievement test. There is a statistically significant increase in the achievement tests, from the pretest $(M=9.42$, $\mathrm{SD}=5.71)$ to the post-test $[\mathrm{M}=26.98, \mathrm{SD}=13.61, \mathrm{t}(34)=8.97, \mathrm{p}<0.05]$. The magnitude of the difference in the means is very large (eta squared $=0.5419)$ (Cohen, 1988). Hence, the first hypothesis is rejected which means that there is significant difference between the mean scores of the achievement test before and after the intervention.

\subsection{Motivation Questionnaire}

The motivation questionnaire was used to assess the students' goals and value beliefs for Chemistry (especially Electrochemistry), their beliefs in their ability to succeed in the subject and their anxiety toward the test and examination on Electrochemistry. Table 12 shows the t-test results for the motivation questionnaire in the study.

Table 12. T-test Table for Students' Motivation Level

\begin{tabular}{cccccc}
\hline Motivation & $\mathrm{N}$ & Mean & Std. Deviation & t value & Sig (2-tailed) \\
\hline Post & 35 & 3.68 & 0.34 & 2.42 & $0.021^{*}$ \\
Pre & 35 & 3.53 & 0.32 & & \\
\hline
\end{tabular}

Data shows that there is a statistically significant increase in the level of motivation from pre-questionnaire $(\mathrm{M}=$ $3.53, \mathrm{SD}=0.32$ ) to the post-questionnaire $[\mathrm{M}=3.68, \mathrm{SD}=0.34, \mathrm{t}(34)=2.42, \mathrm{p}<0.05]$. The eta square is 0.079 , which is considered to be a moderate effect size [41]. Hence, a second hypothesis is rejected; this implies that there is significant difference between the mean scores in motivation before and after intervention.

\section{Discussion}

The most important thing in a multimedia module is how the multimedia elements are used to express the content in a meaningful way and hence, to deliver it effectively to users. The multimedia elements used in IMMPA EC Lab were text, graphic, animation, simulation, video, audio and navigation. All these elements were evaluated in the module evaluation questionnaire. The students rated the highest mean for the graphic element among all the multimedia elements, while the experts' highest mean is for the text element. The use of representational graphic (Levin, 1981) in IMMPA EC Lab made the information easier and more meaningful to the students. Text structures (Armbruster, 1986) and typographical signals made important texts more obvious. Consequently, students can identify the important part of the content and help them to prepare notes in the learning process.

We found that students and experts were having different judgments regarding the PAs in IMMPA EC Lab. Lisa was more favored among the students but the experts preferred Professor T. Students rated Lisa as a better facilitator in learning, more human-like and more engaging as compared to Professor T. On the other hand, experts felt that Professor $\mathrm{T}$ is better at facilitating learning, more credible and more human-like compared to Lisa. Although both students and experts have different views about the PAs, both of them agreed that Professor $\mathrm{T}$ is more credible and Lisa is more engaging. Professor $\mathrm{T}$ as the expert in Electrochemistry always gives accurate information to the students in the learning process, so both students and experts rated him as more credible. On the other hand, Lisa as a learning companion, speaks in an energetic voice and always motivates and encourages the students, hence they rated her as more engaging.

Application of theories gaining very high mean scores indicates that all the content delivery sequence, arrangement of text and graphic, design of the screen, use of multimedia elements, strategy, and techniques used in IMMPA EC Lab were following the principal and concepts in Behaviourism Theory, Cognitivism Theory, Constructivism Theory, Cognitive Load Theory and Cognitive Theory of Multimedia Learning. However, the mean for redundancy effect and redundancy principal is quite low compared to means for other effects in Cognitive Load Theory and principals in Cognitive Theory of Multimedia Learning. Experts felt that texts displayed on the screen when the narration is given are redundant (Craig, Driscoll, \& Gholson, 2004; Craig et al., 2002; Sweller \& Chandler, 1994) to the learners because the information is the same. Students' working memory was loaded because they had to read the text and listen to the narration at the same time. The language used in IMMPA EC Lab is English, following the Teaching and Learning of Science and Mathematics using English Project (Pengajaran dan Pembelajaran Sains dan Matematik dalam Bahasa Inggeris, PPSMI) implemented by the government since 2003. Comprehension of the decoded message is affected by the ability of the receiver to comprehend the message (Heinich, Molenda, Russel, \& Smaldino, 2002). Since English is not our mother tongue, 
it would create problems in delivering information from PAs to students if only audio communication is involved. Hence, on some of the screens, we have decided to deliver the information in both audio and visual forms.

High mean scores for every part in IMMPA EC Lab indicated that the module is reliable to be used as a learning module in Electrochemistry. The items in the module reliability questionnaire were developed according to the activities in IMMPA EC Lab. High mean scores for the module reliability showed that the students were able to follow all the steps and activities in IMMPA EC Lab successfully (Russell, 1974).

The overall mean for module validity is very high indicating that all the experts agreed that the IMMPA EC Lab is a valid learning module according to the characteristics of module validity suggested by Russell (1974). Majority of the experts agreed that the content of IMMPA EC Lab is following the Chemistry syllabus and the students can fulfill all the objectives through the activities designed. The use of animations and videos helped the students in understanding the concepts of Electrochemistry especially at microscopic level.

Students showed improvement in the achievement test, indicating that they gained knowledge about Electrochemistry after learning with IMMPA EC Lab. This showed that IMMPA EC Lab is effective in increasing students' knowledge. However, we found that students are still weak in certain Electrochemistry concepts especially at microscopic and symbolic levels. For instance, the students still could not differentiate between the flow of electrons in the conductors and the flow of ions in the electrolytes (Kamisah \& Lee, 2012; Lee \& Mohammad Yusof, 2009; Lee, 2008; Özkaya, Üce \& Şahin, 2003; Sanger \& Greenbowe, 1997a). Besides that, we found that students always assumed that anions would be attracted to the cathode while cations would be attracted to the anode (Kamisah \& Lee, 2012; Lee \& Mohammad Yusof, 2009; Lee, 2008). This is because anions are negative ions and the students in this study assumed that negative ions would be attracted to negative electrode and vice versa. However, students' results showed improvement from pretest to post-test, indicating that the animations in the Micro-World had helped the students in understanding Electrochemistry concepts microscopically. The use of multimedia creates the environment where students could visualize the abstract chemical processes via animations and videos at macroscopic, microscopic and symbolic levels (Bowen, 1998; Burke et al. 1998; Rodrigues et al. 2001; Russell et al. 1997).

Overall, the students' motivation level increased for each construct in the motivation questionnaire except for the test anxiety construct which maintained the same. The mean value for self-efficacy for learning and performance construct showed the biggest increase from $3.30(\mathrm{SD}=0.42)$ to $3.54(\mathrm{SD}=0.50)$ after the students had studied with the IMMPA EC Lab. Self-efficacy refers to personal beliefs about having the means to learn or perform effectively (Zimmerman, 2000). High self-efficacy beliefs enabled the students to be more motivated to learn Electrochemistry and hence, their test anxiety level was low $(\mathrm{M}=2.06, \mathrm{SD}=0.67)$. High self-efficacy values are related to relatively high intrinsic motivation values. In this study, the students' intrinsic goal orientation value is $3.84(\mathrm{SD}=0.48)$, showing that the students enjoyed learning with the IMMPA EC Lab. The variety of feedback given by the PAs and the videos shown during the discussions attracted the students' attention to study the topic. The students showed the highest extrinsic goal orientation $(\mathrm{M}=4.54, \mathrm{SD}=0.40)$ among all the constructs, indicating that they were trying to show to others that they could perform well in Chemistry.

We considered the suggestions and recommendations by students and experts, and made some corrections and improvements accordingly. For instance, some of the important keywords in the answer scheme were highlighted so that students will take note of them. The button for printing function was added to some of the screens so that users can print out related pages. One of the experts mentioned about adding the concentration cell in IMMPA EC Lab, but we did not consider it because the concentration cell is not in the syllabus for Form Four Chemistry. Some students complained that the background music was annoying and affecting their concentration during the learning process. The background music is actually interactive; users can turn it off if they do not wish to listen. We do not plan to get rid of the background music as some students may have strong musical intelligence and need music in the learning process.

\section{Conclusion}

The formative evaluation has been carried out in the form of objectives-based study and connoisseur-based study approaches involving some students and experts. Students' acquisition of knowledge and motivation levels were tested and measured via the achievement tests and motivation questionnaire. Results showed statistically significant increment of test scores and motivation mean scores after the intervention. The objectives-based study has proven that the IMMPA EC Lab developed is effective in raising students' knowledge and motivation level in the learning of Electrochemistry. This is parallel with studies abroad (Johnson et al., 2000; Kizilkaya \& Askar, 2008; Moundridou \& Virvou, 2002; Moreno, Mayer \& Lester, 2000) where students were found to be more motivated and interested, and achieved higher performance when learning with tutorials supported by PAs. 
On the other hand, the connoisseur-based study involving some experts in Electrochemistry and instructional design was carried out to evaluate the quality of the module developed. Experts rated IMMPA EC Lab as of very high quality and the content is valid. Besides that, results from students also showed that the module is reliable and they managed to carry out the activities in the module.

Suggestions and recommendations from respondents were considered and some corrections have been made to improve the quality of IMMPA EC Lab. We hope that IMMPA EC Lab can meet requirements for students from different backgrounds and become their learning aid in the learning of Electrochemistry. Field trials in the form of summative evaluation would be carried out to evaluate the improved IMMPA EC Lab. The purpose of summative evaluation is to assess the actual implementation of IMMPA EC Lab and study its effectiveness in improving students' knowledge and motivation in learning Electrochemistry. The number of respondents should be increased and another study would be carried out using quasi-experimental design to compare the outcomes between control and treatment groups. It is hoped that the improved IMMPA EC Lab is able to increase students' knowledge and enhance their motivation in the learning of Electrochemistry.

\section{References}

Armbruster, B. B. (1986). Schema theory and the design of content-area textbooks. Educational Psychology, 21(4), 253-267. http://dx.doi.org/10.1207/s15326985ep2104_2

Baylor, A. L., \& Ryu, J. (2003). The effects of image and animation in enhancing pedagogical agent persona. $\begin{array}{llll}\text { Journal of Educational Computing Research, 28(4), 373-394. } & \end{array}$ http://dx.doi.org/10.2190/V0WQ-NWGN-JB54-FAT4

Baylor, A. L., Ryu, J., \& Shen, E. (2003). The Effects of Pedagogical Agent Voice and Animation on Learning, Motivation, and Perceived Persona. Paper presented at Annual World conference of Educational Multimedia, Hypermedia, \& Telecommunication. Honolulu, Hawaii, 23-28 Jun.

Bojczuk, M. (1982). Topic Difficulties in O- and A-Level Chemistry. School Science Review, 64, 545-551.

Bowen, C. W. (1998). Item Design Considerations for Computer-Based Testing of Student Learning in Chemistry. Journal of Chemical Education, 75, 1172-1175. http://dx.doi.org/10.1021/ed075p1172

Brünken, R., Plass, J. L., \& Leutner, D. (2004). Assessment of Cognitive Load in Multimedia Learning with Dual-Task Methodology: Auditory Load and Modality Effects. Instructional Science, 32, 115-132. http://dx.doi.org/10.1023/B:TRUC.0000021812.96911.c5

Burke, K. A, Greenbowe, T. J., \& Windschitl, M. A. (1998). Developing and Using Conceptual Computer Animations for Chemistry Instruction. Journal of Chemical Education, 5, 1658-1661. http://dx.doi.org/10.1021/ed075p1658

Chandler, P., \& Sweller, J. (1992). The Split-Attention Effect as a Factor in the Design of Instruction. British Journal of Educational Psychology, 62, 233-246. http://dx.doi.org/10.1111/j.2044-8279.1992.tb01017.x

Chou, C. Y., Chan, T. W., \& Lin, C. J. (2003). Redefining the learning companion: the past, present and future $\begin{array}{llll}\text { of educational agents. Computers \& Education, } 40, & \text { 255-269. }\end{array}$ http://dx.doi.org/10.1016/S0360-1315(02)00130-6

Clarebout, G., \& Elen, J. (2007). In Search of Pedagogical Agents' Modality and Dialogue Effects in Open Learning Environments. Retrieved July 23, 2009, from http://www.ascilite.org.au/ajet/ejist/docs/vol10_no1/papers/full_papers/clarebout_elen.pdf

Cohen, J. (1988). Statistical Power Analysis for the Behavioral Sciences. Hillsdale, NJ: Erlbaum.

Craig, S. D., Driscoll, D. M., \& Gholson, B. (2004). Constructing Knowledge from Dialog in an Intelligent Tutoring System: Interactive Learning, Vicarious Learning and Pedagogical Agents. Journal of Educational Multimedia and Hypermedia. 13, 163-183.

Craig, S. D., Gholson, B., \& Driscoll, D. M. (2002). Animated Pedagogical Agents in Multimedia Educational Environments: Effects of Agent Properties, Picture Features and Redundancy. Journal of Educational Psychology, 94, 428-434. http://dx.doi.org/10.1037/0022-0663.94.2.428

Dick, W., \& Carey, L. (1991). The Systematic Design of Educational Technologies. Hillsdale, NJ: Erlbaum.

Doymus, K., Karacop, A., \& Simsek, U. (2010). Effects of jigsaw and animation techniques on students' understanding of concepts and subjects in electrochemistry. Education Technology Research \& Development, 58, 671-691. http://dx.doi.org/10.1007/s11423-010-9157-2 
Flagg, B. N. (1990). Formative Evaluation for Educational Technologies. Hillsdale, NJ: Erlbaum.

Garnett, P. J., \& Hackling, M. W. (1993). Chemistry Misconceptions at the Secondary-Tertiary Interface. Chemistry in Australia, 60(3), 117-119.

Garnett, P. J., \& Treagust, D. F. (1992). Conceptual Difficulties Experienced by Senior High School Students of Electrochemistry: Electrochemical (Galvanic) and Electrolytic Cells. Journal of Research in Science Teaching, 29(10), 1079-1099. http://dx.doi.org/10.1002/tea.3660291006

Garnett, P. J., Garnett, P. J., \& Hackling, M. W. (1995). Students' Alternative Conceptions in Chemistry: A Review of Research and Implications for Teaching and Learning. Studies in Science Education, 25, 69-95. http://dx.doi.org/10.1080/03057269508560050

Gerlach, V. S., \& Ely, D. P. (1980). Teaching and Media: A Systematic Approach (2nd ed.). New Jersey: Prentice-Hall, Inc.

Gois, J. Y., \& Giordan, M. (2009). Evolution of virtual learning environments in chemistry education. In: Enseñanza de las Ciencias, Número Extra VIII Congreso Internacional sobre Investigación en Didáctica de las Ciencias, Barcelona, pp. 2864-2867.

Gustafson, K. L., \& Branch, R. M. (1997). Survey of Instructional Development Model (3rd ed.). NY: ERIC Clearinghouse on Information Technology.

Heinich, R., Molenda, M., Russel, J. D., \& Smaldino, S. E. (2002). Instructional Media and Technologies for Learning (7th ed.). New Jersey: Merrill Prentice Hall.

Hill, J. R., \& Hannafin, M. J. (2001). Teaching and Learning in Digital Environments: The Resurgence of Resourse-Based Learning. Educational Technology Research \& Development, 49(3), 37-52. http://dx.doi.org/10.1007/BF02504914

Johnson, W. L., Rickel, J. W., \& Lester, J. C. (2000). Animated pedagogical agents: face-to-face interaction in interactive learning environments. International Journal of Artificial Intelligence in Education, 11, 47-78.

Kamisah Osman., \& Lee, T. T. (2012). Interactive Multimedia Module with Pedagogical Agent in Electrochemistry. In I. Deliyannis (Eds.), Interactive Multimedia (pp. 29-48). Croatia: InTech.

Karsli, F., \& Çalik, M. (2012). Can Freshman science Student Teachers' Alternative Conceptions of 'Electrochemical Cells' be Fully Diminished? Asian Journal of Chemistry, 24(2), 485-491.

Kemp, J. E., Morrison, G. R., \& Ross, S. V. (1994). Design effective instruction. New York: Macmillan.

Kemp, J. E., Morrison, G. R., \& Ross, S. V. (2004). Design Effective Instruction (4th ed.). New York: John Wiley \& Sons.

Kirk, K. (2008). Performance, Perception and Choice of Animated Pedagogical Agent. Ph.D. Thesis, University of Nevada, Las Vegas.

Kizilkaya, G., \& Askar, P. (2008). The effect of an embedded pedagogical agent on the students' science achievement. Interactive Technology and Smart Education, 5(4), 208-216. http://dx.doi.org/10.1108/17415650810930893

Land, S. M. (2000). Cognitive Requirements for Learning with Open-Ended Learning Environments. Educational Technology Research \& Development, 48(3), 61-78. http://dx.doi.org/10.1007/BF02319858

Lee, T. T. (2008). Kefahaman Pelajar Tingkatan Empat Mengenai Elektrokimia. Master Thesis, Universiti Teknologi Malaysia.

Lee, T. T., \& Kamisah Osman. (2010). Pembinaan Modul Multimedia Interaktif dengan Agen Pedagogi (IMMPA) dalam Pembelajaran Elektrokimia: Analisis Keperluan. Paper presented at Kolokium Kebangsaan Pasca Siswazah Sains \& Matematik 2010, Universiti Pendidikan Sultan Idris, December 22, 2010.

Lee, T. T., \& Mohammad Yusof Arshad. (2009). Miskonsepsi Pelajar Tingkatan Empat Mengenai Elektrokimia. Jurnal Sains dan Matematik UPSI, 1(2), 52-64.

Lee, T. T., \& Kamisah Osman. (2012). Students' Characteristics: Implications to the Design of Interactive Multimedia Module with Pedagogical Agent (IMMPA) in the Learning of Electrochemistry. Research Journal of Applied Sciences, 7(3), 177-184. http://dx.doi.org/10.3923/rjasci.2012.177.184

Lerman, Z. M., \& Morton, D. (2009). Using the Arts and Computer Animation to Make Chemistry Accessible to All in the Twenty-First Century. In: Gupta-Bhowan M, Jhaumeer-Laulloo S, Li Kam Wah H, Ramasami P, 
editors. Chemistry Education in the ICT Age. Mauritius: Springer Science + Business Media B.V. pp. 31-40.

Levin, J. R. (1981). On the functions of pictures in prose. In F. J. Pirozzolo \& M. C. Wittrock, (Eds.), Neuropsychological and Cognitive Processes in Reading (pp. 203-228). New York: Academic Press.

Lin, H. S., Yang, T. C., Chiu, H. L., \& Chou, C. Y. (2002). Students' Difficulties in Learning Electrochemistry. Proc. Natl. Sci. Counc. ROC(D), 12(3), 100-105.

Mayer, R. E., \& Moreno, R. (1998). A Split-Attention Effect in Multimedia Learning: Evidence for Dual Processing Systems in Working Memory. Journal of Educational Psychology, 90(2), 312-320. http://dx.doi.org/10.1037/0022-0663.90.2.312

Mayer, R. E., Dow, G. T., \& Mayer, S. (2003). Multimedia Learning in an Interactive Self-Explaining Environment: What Works in the Design of Agent-Based Microworlds? Journal of Educational Psychology, 95(4), 806-813. http://dx.doi.org/10.1037/0022-0663.95.4.806

Mayer, R. E., Fennell, S., Farmer, L., \& Campbell, J. (2004). A Personalization Effect in Multimedia Learning: Students Learn Better When Words Are in Conversational Style Rather Than Formal Style. Journal of Educational Psychology, 96(2), 389-395. http://dx.doi.org/10.1037/0022-0663.96.2.389

Mayer, R. E., Sobko, K., \& Mautone, P. D. (2003). Social Cues in Multimedia Learning: Role of Speaker's Voice. Journal of Educational Psychology, 95(2), 419-425. http://dx.doi.org/10.1037/0022-0663.95.2.419

Moreno, R., \& Mayer R. E. (2000). Pedagogical agents in constructivist multimedia environments: The role of image and language in the instructional communication. Retrieved July 15, 2009 from http://www.unm.edu/ moreno/PDFS/Roundtble.pdf.

Moreno, R., \& Mayer, R. E. (1999). Cognitive Principles of Multimedia Learning: The Role of Modality and Contiguity. Journal of Educational Psychology, $258-368$. http://dx.doi.org/10.1037/0022-0663.91.2.358

Moreno, R., Mayer, R. E., \& Lester, J. C. (2000). Life-Like Pedagogical Agents in Constructivist Multimedia Environments: Cognitive Consequences of their Interaction. Retrieved July 16, 2009 from http://www.unm.edu/ moreno/PDFS/ED-MEDIA-DAP.pdf.

Morrison, G. R., Ross, S. M., \& Kemp, J. E. (2007). Designing Effective Instruction (5th ed.). NY: John Wiley \& Sons, Inc.

Moundridou, M., \& Virvou, M. (2002). Evaluating the Persona Effect of an Interface Agent in an Intelligent Tutoring System. Journal of Computer Assisted Learning, 18(2), Retrieved from http://thalis.cs.unipi.gr/ mariam/JCAL.pdf.

Mousavi, S., Low, R., \& Sweller, J. (1995). Reducing cognitive load by mixing auditory and visual presentation modes. Journal of Educational Psychology, 87, 319-334. http://dx.doi.org/10.1037/0022-0663.87.2.319

Needham, R. (1987). CLIS in the Classroom: Teaching Strategies for Developing Understanding in Science. Leeds: University of Leeds.

Özkaya, A. R., Üce, M., \& Şahin, M. (2003). Prospective Teachers' Conceptual Understanding of Electrochemistry: Galvanic and Electrolytic Cells. University Chemistry Education, 7(1), 1-12.

Paas, F. G. W. C., \& Van Merriënboer, J. J. G. (1994). Variability of Worked Examples and Transfer of Geometrical Problem-Solving Skills: A Cognitive-Load Approach. Journal of Educational Psychology, 86(1), 122-133. http://dx.doi.org/10.1037/0022-0663.86.1.122

Paas, F., Renkl, A., \& Sweller, J. (2003). Cognitive Load Theory and Instructional Design: Recent Developments. Educational Psychologist, 38(1), 1-4. http://dx.doi.org/10.1207/S15326985EP3801_1

Pintrich, R. R., \& DeGroot, E. V. (1990). Motivational and self-regulated learning components of classroom academic performance. Journal of Educational Psychology, 82, 33-40. http://dx.doi.org/10.1037/0022-0663.82.1.33

Pollock, E., Chandler, P., \& Sweller, J. (2002). Assimilating complex information. Learning and Instruction, 12, 61-86. http://dx.doi.org/10.1016/S0959-4752(01)00016-0

Predinger, H., Saeyor, S., \& Ishizuka, M. (n.d.). Animated Agents for Language Conversation Training. Retrieved July 15, 2009 from http:/www.miv.t.u-tokyo.ac.jp/papers/helmut-edmedia01.pdf 
Qureshi, E. (2001, 2004). Instructional Design Models. Retrieved September 24, 2009 from $\mathrm{http}: / /$ web2.uwindsor.ca/courses/edfac/morton/instructional_design.htm

Qureshi, E. (2003). Instructional Design Models. Retrieved September 24, 2009 from $\mathrm{http} / / /$ home.comcast.net/ elenaqureshi/IDModels.htm

Rodrigues, S., Smith, A., \& Ainley, M. (2001). Video clips and animation in chemistry CD-ROMS: Student interest and Preference. Australian Science Teachers Journal, 47(2), 9-15.

Roziah Abdullah. (2005). Pembangunan dan Keberkesanan Pakej Multimedia Kemahiran Berfikir bagi Mata Pelajaran Kimia. Ph.D. Thesis, Universiti Kebangsaan Malaysia.

Russell, J. D. (1974). Modular Instruction: A Guide to the Design, Selection, Utilization and Evaluation of Modular Materials. Minneapolis, Minnesota: Burgess Publishing Company.

Russell, J. W., Kozma, R. B., Jones, T., Wykoff, J., Marx, N., \& Davis, J. (1997). Use of Simultaneous-Synchronized Macroscopic, Microscopic, and symbolic Representations to Enhance the Teaching and Learning of Chemical Concepts. Journal of Chemical Education, 74(3), 330-334. http://dx.doi.org/10.1021/ed074p330

Sadiah Baharom., Ong, E. T., Marzita Putih., Sopia Mad Yassin., Nurul Huda Abd. Rahman., Muhamad Ikhwan, \& Mat. Saad. (2009). The Validation and adaptation of MLSQ aimed to assess student use of self regulated learning. Paper presented at $I^{\text {st }}$ International Conference on Educational Research and Practice Enhancing Human Capital through Teacher Education, 10-11 June, Faculty of Educational Studies, UPM, Serdang.

Sanger, M. J., \& Greenbowe, T. J. (1997a). Common Student Misconceptions in Electrochemistry: Galvanic, Electrolytic, and Concentration Cells. Journal of Research in Science Teaching, 34(4), 377-398. http://dx.doi.org/10.1002/(SICI)1098-2736(199704)34:4<377::AID-TEA7>3.0.CO;2-O

Sanger, M. J., \& Greenbowe, T. J. (1997b). Students' Misconceptions in Electrochemistry: Current Flow in Electrolyte Solutions and the Salt Bridge. Journal of Chemical Education, 74, 819-823. http://dx.doi.org/10.1021/ed074p819

Sidek Mohd Noah., \& Jamaludin Ahmad. (2005). PEMBINAAN MODUL: Bagaimana Membina Modul Latihan dan Modul Akademik. Serdang: Penerbit Universiti Putra Malaysia.

Slater, D. (2000). Interactive Animated Pedagogical Agents Mixing the Best of Human and Computer-Based Tutors. Master Thesis, Stanford University.

Sweller, J., \& Chandler, P. (1994). Why some material is difficult to learn? Cognition and Instruction, 12(3), 185-233. http://dx.doi.org/10.1207/s1532690xci1203_1

Van Gerven, P. W. M., Paas, F. G. W. C., Van Merriënboer, J. J. G., \& Schmidt, H. G. (2002). Cognitive load theory and aging: effects of worked examples on training efficiency. Learning and Instruction, 12, 87-105. http://dx.doi.org/10.1016/S0959-4752(01)00017-2

Van Merriënboer, J, J, G., Kirschner, P. A., \& Kester, L. (2003). Taking the Load off a Learner's Mind: Instructional Design for Complex Learning. Educational Psychologist, 38(1), 5-13. http://dx.doi.org/10.1207/S15326985EP3801_2

Zimmerman, B. J. (2000). Attaining self-regulation: a social-cognitive perspective. In M. Boekaerts, P. R. Pintrich, M. Zeidner (Eds.), Handbook of Self-Regulation. San Diego: Academic Press. 